\title{
Pre-Acadian Cajun French
}

\author{
LUC V. BARONIAN
}

Université de Montréal and University of Ottawa

\section{About this Paper}

This paper challenges the "general consensus" according to which Cajun French is most interestingly contrasted with Louisiana Creole, and proposes a parish-toparish comparison approach to help us understand the genesis of Cajun French.

Perhaps because the term Cajun traces its etymology to the word Acadian, little attention has been given to the historical ties of Louisiana French with the Québécois, French and Haitian settlers of Louisiana. I hence decided to take these historical ties seriously and looked for linguistic features that could help link Cajun French to non-Acadian varieties. The data comes from original fieldwork conducted in the summer of 2003.

This study should then be of particular interest to French and North American French linguists, but also of general interest to sociolinguists concerned with the questions of dialect formation and contact.

\section{About Louisiana French and Creole}

Nowadays in Louisiana, "Cajun French" is typically the label for the varieties of French spoken by people of European origin in the 22 parishes (counties) of southern Louisiana forming the region known as Acadiana (see map in Figure 1). However, some speakers of European origin who actually speak what linguists call a creole also label their speech as "Cajun French" (see Klingler 2003a, 2003b). In parallel, "Creole" is usually the label used for varieties of both Creole and French, as spoken by people of African origin. Because of these overlapping labels, we will adopt the following terminology for the present paper:

\footnotetext{
* I am highly indebted to Joe and Runnie Matte (Evangeline), Mr. and Mrs. Steven Alcide Broussard (Vermilion), as well as Michelle Benoit and Glen Pitre (Lafourche) for introducing me to several speakers in the three parishes studied here. Special thanks also go to Tom Klingler (Tulane University) and Bernie Ricard, who introduced me to speakers, helped me find my way and feel at home more than once. The interviewed speakers are too numerous to be named here, but I do thank them from the bottom of my heart. I acknowledge a Graduate Research Opportunity grant from Stanford University for the completion of the fieldwork.
} 
(1) Acadiana or Cajun French: The varieties of French spoken by both Cajuns and Creoles in the triangle of 22 parishes (counties) designated as "Acadiana" by the Louisiana government.

Louisiana Creole: The varieties of the French-based creole spoken in Louisiana, mainly in eastern parts of Acadiana (Pointe Coupée, St. John, St. James, St. Martin, etc.).

It should also be noted that there are isolates of French and Creole in other parishes, such as Natchitoches, St. Tammany, and Plaquemines. Varieties of French and Creole were also once widely spoken in New Orleans, of course, though it is often said that New Orleans French was much closer to Standard French.

Figure 1: The Acadiana parishes' Triangle

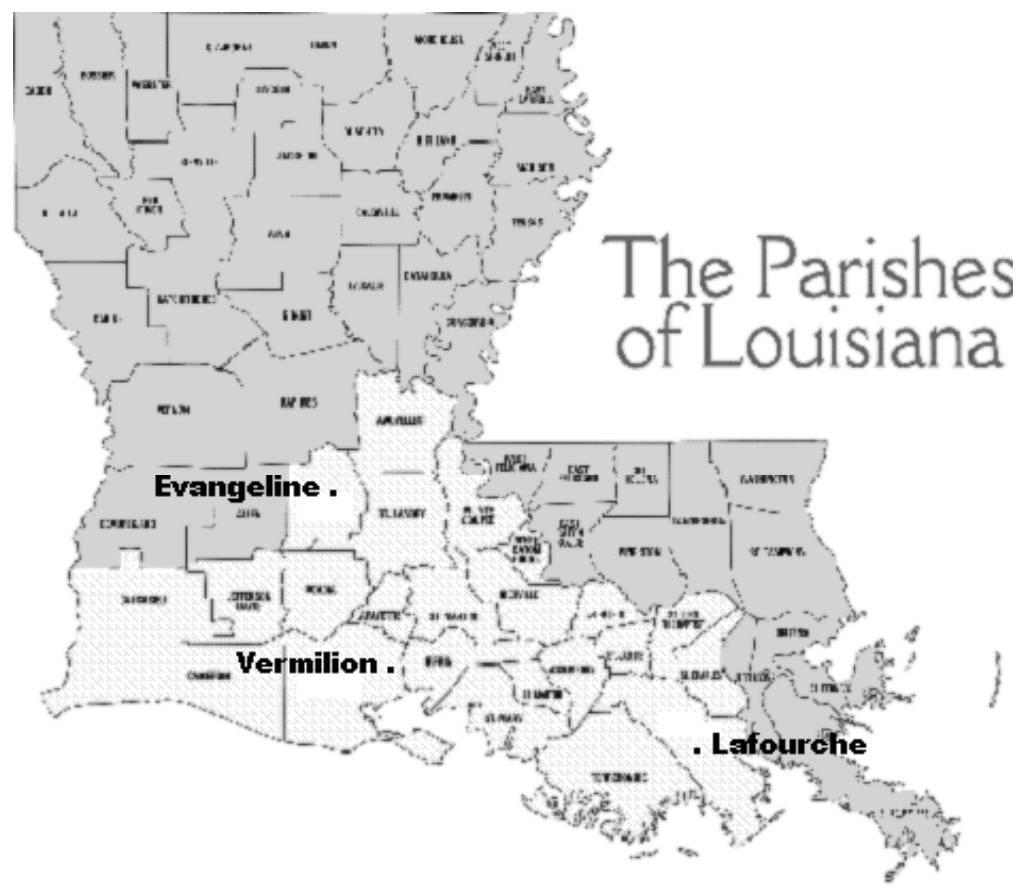

${ }^{1}$ Map colored in by Luc Baronian from an image on the Louisiana government website (free of rights). 


\section{About Cajuns}

The term "Cajun" is etymologically derived from the word Acadian, referring to the inhabitants of the French colony of Acadie/Acadia (today: Nova Scotia, Prince Edward Island and southern New Brunswick, Canada). Starting in 1755, Acadians were dispersed by the British across the Atlantic. While some were able to settle in Quebec and northern New Brunswick, many lived as refugees in the British American colonies, the Caribbean, France, and England for several years. Eventually, the governor of Louisiana allowed them to settle in this colony. The story of a typical Acadian family is shown in Figure 2.

Figure 2: Dispersion of the Bastarache dit Basque family ${ }^{2}$

Jean (Joannis) Bastarache dit le Basque \& Huguette Vincent
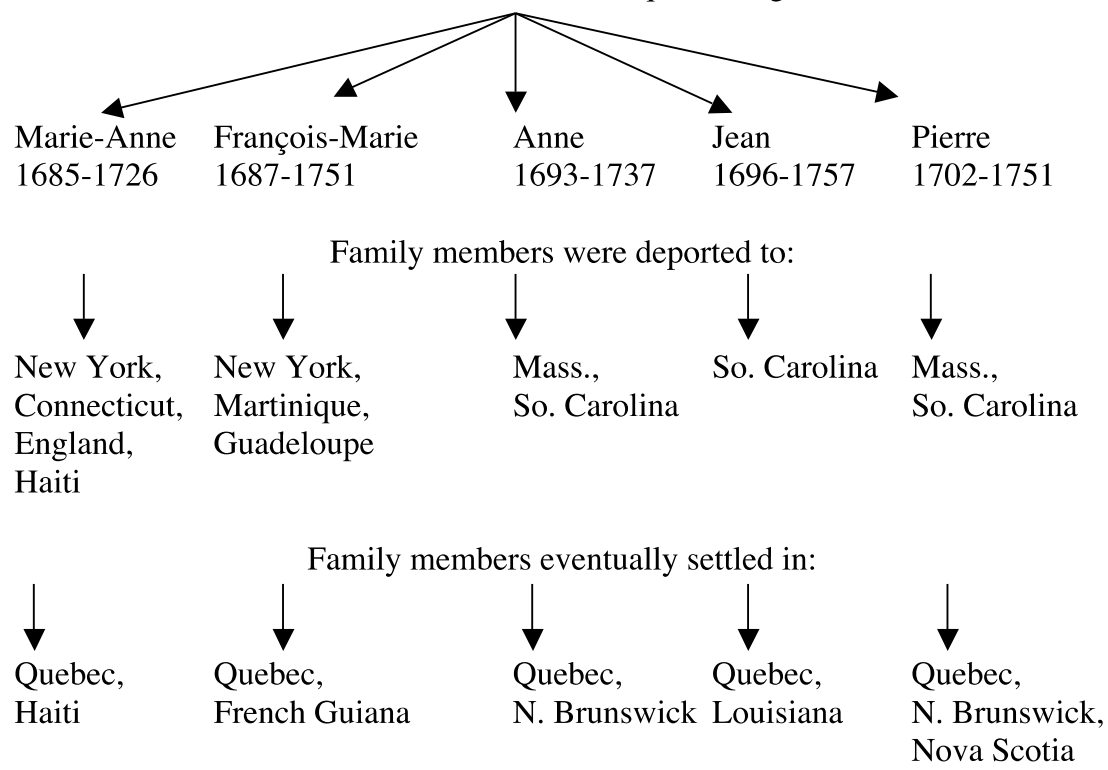

There is much less discussion in the available literature surrounding the history of the non-Acadian settlers of Louisiana. Before the arrival of the Acadians, the French administrators of Louisiana first tried to attract French-Canadians from Quebec. Though some did settle in Louisiana, overall, these attempts did not have much success, because these individuals tended to be traders who preferred their traveling way of life along the Mississippi. After the conquest of Canada and Eastern Louisiana in 1763, some settlers came from Mobile, Alabama (then part

\footnotetext{
2 Adapted from the website of the Association des familles Bastarache, Bastrache et Basque Inc. (www.bastarache.org).
} 


\section{Luc V. Baronian}

of Louisiana). Many Francophone settlers also came from Haiti/Saint-Domingue, during the Rebellions of the Slaves in 1804 and the independence of that country. Settlers from France came at every period of Louisiana's history, including in the $20^{\text {th }}$ century when Cajun soldiers brought back French wives from World Wars I and II. The descendants of these non-Acadian settlers were historically known as Petits Créoles (in Acadiana, as opposed to the New Orleans aristocratic Creoles), Créole blancs, or simply Créoles, thus adding to the confusion between the terms Cajun and Creole. ${ }^{3}$

\section{The Problem}

In spite of the various origins of the French settlers of Louisiana, it is generally assumed that Cajun French is rather uniform from one end of Acadiana to another, perhaps because, as we have seen, the term Cajun now refers to the descendants of all the French settlers of rural Louisiana.

Though linguists at one time distinguished between "colonial" French, Acadian French and Creole French, the general consensus today is that colonial and Acadian French have melded to a great degree into a "Cajun" variety which can be distinguished from Creole.

LaFleur (Ms.)

First, the purpose of this paper is certainly not to disprove completely this "general consensus." Indeed, varieties of French in Louisiana do share many innovations. To name a few:

(2) -Replacement of the verb savoir by connaitre 'know'.

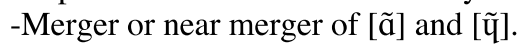

-Replacement of the word coq by game 'rooster'.

-A progressive construction involving the word après 'after/onto'.

-Loan English verbs without French verbal morphology: $j$ 'ai drive. ${ }^{4}$

Of course, there are also local innovations specific to a parish or an area. The long-term goal that this paper addresses is to answer as best we can the question of the genesis of Acadiana French. That is:

(3) -Was the arrival of Acadians so massive that it wiped out all traces of other French varieties?

-Did Acadians assimilate to the French variety (varieties) that was (were) already in place in rural Louisiana?

-Are we dealing with an interesting mix of the two possibilities?

-If we are dealing with an intermediate situation, what features can we attribute to Acadians, and what features can we attribute to non-Acadians?

\footnotetext{
${ }^{3}$ See Brasseaux (1987) for more on settlement patterns in French Louisiana.

${ }^{4}$ See Brown (2003).
} 
While it is beyond the scope of this paper to answer these questions exhaustively, I will demonstrate that five features indicate at least a partial survival of pre-Acadian varieties in modern Cajun French.

\section{The Data}

In the summer of 2003, I conducted a linguistic survey in Acadiana, thanks to a Graduate Research Opportunity grant from Stanford University. The survey consisted of asking native speakers of Acadiana French to translate words, small phrases and sentences of English into French. While the use of spontaneous natural discourse is usually the preferred method of data collecting in sociolinguistics, the purpose of this investigation necessitated the elicitation method. Indeed, because I was interested in comparing known features of Acadiana French in several parishes, and because time spent in the field is expensive and funding is always limited, how long would I have had to wait to collect all the features in similar contexts in all the parishes? And how long would it have taken before a significant number of speakers had uttered the researched features?

My main assumption is that the translation method allowed me to collect the spontaneous way in which the speakers would say the intended meaning. There is of course a bias due to interference with English, but in principle it was uniform across all parishes, since nearly all speakers were very fluent in English.

Interviews with the speakers (aged between 40 and 95 years old) were recorded on analog tapes, which were later digitized. The questions were asked orally. Nearly all speakers were not able to read or write French and had only had limited contact with Francophones from outside Louisiana. The data collected in three parishes will be of interest to us: ${ }^{5}$

(4) Evangeline Parish: Not settled by Acadians.

Vermilion Parish: Settled mainly by Acadians.

Lafourche Parish (southern part): Not settled by Acadians.

\section{The Reasoning}

As can be seen on the map of Louisiana in Figure 1, Evangeline and Lafourche are located at opposite ends of the Acadiana triangle; they are peripheral parishes. A linguistic feature specific to a dialect can either be the preservation of an older state (also known as an archaism) ${ }^{6}$ or be an innovation with respect to the older state, perhaps still preserved in other dialects. A well-known principle of dialectology is that feature realizations that are found in non continuous areas at the periphery of a linguistic domain are usually preservations. Indeed, it would be a coincidence for two distant dialects to both innovate in the same way, and unless there are special circumstances, it is hard to conceive how an innovation can

\footnotetext{
${ }^{5}$ See Brasseaux (1987) for the history of Acadian settlements.

${ }^{6}$ The word archaism has a pejorative connotation to me, so I will use preservation instead, just like most linguists prefer to use innovation instead of corruption.
} 
Luc V. Baronian

spread to a distant area by hopping over an area located in the middle.

If, however, we find at the periphery features that we know to be innovations with respect to European French, the logical conclusion is that the linguistic ancestors of the speakers at the periphery once shared a closer linguistic space that was interrupted by the arrival of another population in the center. A more radical example can be found in the Celtic languages of Great Britain: the continuity between Scotts Gaelic, Cornish and Welsh is interrupted by large Anglophone areas.

Hence, I will consider five features of Cajun French and show that in all five cases, Evangeline and southern Lafourche speakers realize these features in the same way, while Vermilion is the divergent dialect for these features.

\section{The Five Features}

Below is a description of the five features from my 2003 linguistic survey, known to be divergent from Standard French in Acadiana French, and that will be relevant for discussion later. For each feature, I state which realization is most likely to be the innovative one.

(5)

i. Pourquoi vs. quoi faire: French pourquoi 'why' replaced by the locution quoi faire [kofer], possibly from an intermediate stage pourquoi faire 'why to do', attested in Quebec. Speakers were asked to translate the sentence Why aren't you ready? In this case, quoi faire is clearly the innovation, while pourquoi is the preservation.

ii. Quoi vs. Qui: Modern Standard French has quelquoi 'what' and qui 'who'. In the classical language, qui was used for both animate and inanimate. It seems then that quoi $[\mathrm{kwa}]$ is the innovation, while qui [ki] is a preservation. However, even after consulting the Französiches etymologisches wörterbuch (FEW), it is not clear to me when qui started to be used. It is possible that both $q u i$ and quoi are separate innovations. Speakers were asked to translate the sentences What are you doing? and What's bothering you?

iii. Queue vs. Tcheue: French queue 'tail' pronounced [t $\left.\int \varnothing\right]$ instead of [kø]. Palatalization is much more frequent in Louisiana and in the Francophone world in general in front of front glides than in front of front vowels. In the Atlas linguistique de France (Gilliéron and Edmont 1902-1910), [t $\left.\int \varnothing\right]$ is limited to a central western area and is clearly the innovation.

iv. Permissive Laisser vs. Quitter: French permissive verb laisser 'let' is replaced by quitter 'leave'. Speakers were asked to translate several sentences with English let. The variant quitter is the innovation here. 
v. The devil and his wife: Attestation of an expression involving the devil beating his wife and/or marrying his daughter to describe a combination of sun and rain. Similar expressions are attested in American English, in Quebec French, and in other European languages. See postings by Bert Vaux on www.linguistlist.org for a cross-linguistic overview. I will consider the presence of the expression as an innovation.

\section{The Results}

In this section, I lay out the results from the survey for the five features described in the previous section in the three parishes of interest: southern Lafourche, Evangeline and Vermilion.

Table 1: Southern Lafourche Parish (non-Acadian)

\begin{tabular}{llllll} 
& i & ii & iii & iv & v \\
L1 & $1 / 1$ & $0 / 2$ & $1 / 1$ & $11 / 11$ & $1 / 1$ \\
L2 & $0 / 1$ & $0 / 2$ & $1 / 1$ & $1 / 11$ & $1 / 1$ \\
L3 & $1 / 1$ & $0 / 2$ & $1 / 1$ & $9 / 9$ & $0 / 1$ \\
L4 & $1 / 1$ & $0 / 2$ & $1 / 1$ & $11 / 11$ & $1 / 1$ \\
L5 & $1 / 1$ & $0 / 1$ & $1 / 1$ & $11 / 11$ & $0 / 1$ \\
L6 & $1 / 1$ & $0 / 2$ & $1 / 1$ & $11 / 11$ & $1 / 1$ \\
\hline$\%$ & 83 & 0 & 100 & 84 & 67
\end{tabular}

Table 2: Evangeline Parish (non-Acadian)

\begin{tabular}{llllll} 
& i & ii & iii & iv & v \\
E1 & $\ldots$ & $0 / 2$ & $1 / 1$ & $7 / 8$ & $1 / 1$ \\
E2 & $\ldots$ & $0 / 2$ & $1 / 1$ & $2 / 8$ & $0 / 1$ \\
E3 & $1 / 1$ & $0 / 2$ & $1 / 1$ & $6 / 7$ & $0 / 1$ \\
E4 & $1 / 1$ & $0 / 2$ & $1 / 1$ & $7 / 7$ & $1 / 1$ \\
E5 & $1 / 1$ & $0 / 2$ & $1 / 1$ & $6 / 6$ & $0 / 1$ \\
\hline$\%$ & 100 & 0 & 100 & 80 & 40
\end{tabular}

Table 3: Vermilion Parish (largely Acadian)

\begin{tabular}{|c|c|c|c|c|}
\hline $\mathrm{i}$ & ii & iii & iv & $\mathrm{v}$ \\
\hline $\mathrm{V} 10 / 1$ & $2 / 2$ & $0 / 1$ & $2 / 11$ & $0 / 1$ \\
\hline V2 $0 / 1$ & $2 / 2$ & $0 / 1$ & $8 / 13$ & $0 / 1$ \\
\hline V3 0/1 & $2 / 2$ & $1 / 1$ & $10 / 11$ & $0 /$ \\
\hline V4 ... & $2 / 2$ & $1 / 1$ & $0 / 3$ & $0 /$ \\
\hline V5 $1 / 1$ & $2 / 2$ & $0 / 1$ & $11 / 11$ & $0 /$ \\
\hline V6 0/1 & $2 / 2$ & $0 / 1$ & $0 / 9$ & $0 /$ \\
\hline V7 0/1 & $2 / 2$ & $0 / 1$ & $5 / 10$ & $0 /$ \\
\hline$\% \quad 17$ & 100 & 29 & $46 / 5$ & \\
\hline
\end{tabular}


The features are numbered (i) through (v) as in the previous section, while the speakers are given a capital letter (L, E or V) identifying the parish and a number. The numbers inside the tables count the number of innovative realizations of the feature per number of times the speaker was questioned on this feature. Thus, speaker L1 used quoi faire once out of one, inanimate qui twice out of two, etc. Percentages are calculated on the bottom line.

At first glance, the percentages for the two parishes where few or no Acadians have settled seem to be more comparable with each other than with those of Vermilion parish. Lafourche and Evangeline share one preservation (ii) and four innovations. To the extent that the results are statistically significant (see next section), this indicates that the linguistic predecessors of the Evangeline and Lafourche speakers must have shared a community of speech not shared with those of Vermilion, a community in which the four innovations could have spread.

After conducting the fieldwork, it came to my attention that Rottet (2004) has already observed that the preservation of inanimate qui seems to be restricted to non-Acadian areas. However, because it is the presumed older form that is attested in Evangeline and Lafourche, this feature is not quite as convincing as the four others. Indeed, it could simply be that Vermilion once had the older form and that the innovation has sprouted there without yet spreading to the rest of the territory. Although if Rottet is right in stating that all the Acadian areas of Louisiana have quoi and all the non-Acadian ones have qui (with perhaps a mix in the mixed areas), then this would appear as a strange coincidence, and we would have to conclude that quilquoi variation is indeed tied to the settlement history.

A note is also in order regarding feature (iii), queueltcheue. This palatalization is famous in Acadian French as spoken today in Atlantic Canada (see Cormier 1999); however, it is not the pronunciation of all Acadian speakers of Canada and it is also attested in Quebec (see Dulong and Bergeron 1980). The innovative tcheue could therefore have come to Evangeline and Lafourche from Quebec, whereas the form queue could have come from a more conservative form of Acadian French than the contemporary ones with tcheue.

In general, I wish to make no claim as to where each innovative trait came from. They could have evolved separately in Louisiana, or they could have been brought from Quebec, Haiti, Acadia, or France. It does not really matter for the purposes of the demonstration. It would of course be of additional interest if innovations shared by Evangeline and Lafourche could be shown not to have come from anywhere else in the Francophone world, because that would entail that the linguistic ancestors of those parishes' speakers once shared a continuous speech community in Louisiana. However, realistically, because the time period between the arrival of the first French settlers of Louisiana and the first Acadian settlers was less than a century, we cannot expect to find many such features. It is therefore sufficient to prove simply that the linguistic ancestors of the speakers of Evangeline and Lafourche parishes once shared a continuous speech community, whether this speech community was in Louisiana, Quebec, Haiti, or France. 


\section{Significance of the Results}

In this short section, I discuss the statistical significance of the results laid out in the previous section. Innovation (i) is significantly less present in (Acadian) Vermilion than in the other two parishes ( $90 \%$ confidence). Innovation (ii) (quoi) is unattested in both Evangeline and Lafourche. Conversely, however, qui is unattested in the Acadian parish of Vermilion, so there is at least a correlation between Acadian quoi and non-Acadian qui. This result is consistent with the observations of Rottet (2004) and Byers (1988). Innovation (iii) is significantly less present in Vermilion parish than in the other two parishes ( $90 \%$ confidence). Innovation (iv), when the total number of occurrences are counted, is significantly less present in Vermilion parish (90\% for Evangeline; $95 \%$ for Lafourche). However, on a speaker-based comparison, the difference is not significant (when one averages the speaker averages, percentage noted by an asterisk in Table 3). Innovation (v) is unattested in Vermilion.

\section{Conclusion}

While there may always be an alternative explanation available for the history of any given feature, taken together, the results for the five features under scrutiny are encouraging and indicate that there are shared innovations between the distant Evangeline and Southern Lafourche parishes not shared or significantly less shared with the Acadian parish of Vermilion.

Hence, these are probably remnants of pre-Acadian French in Louisiana. Because the Acadian and non-Acadian varieties have lived next to one another for over two centuries, they have undergone common changes. This makes it look today as if all the varieties of Acadiana French stem from a single ancestor in a prototypical stembaum model. Garrett (2003) argues similarly that there never was a proto-Greek. The distribution of innovative features is such that it is impossible to reconstruct a prototypical dialect tree with a common ancestor and several sub-groupings branching off in an orderly fashion. Instead, it is more logical to think of early Greek as a set of closely related dialects whose innovations spread from one neighbor to another. Likewise, I suggest that the genesis of what is today perceived as a rather uniform Cajun French is no different, with the notable exception that we pretty much know the settlement history of French Louisiana down to the man and woman, while we can only speculate as to the origins of the Indo-European settlers of the Greek peninsula.

A plausible scenario is that first some settlers came from French Canada (Quebec) in the early $18^{\text {th }}$ century, bringing their dialect with them, along with some settlers from France. (A stream of settlers from Quebec and France would come throughout the next two centuries.) Later, settlers of the defeated colony of Mobile, AL settled rural Louisiana as well. Roughly at the same time, Africans in Louisiana were developing their own Creole. Shortly afterwards, Acadians arrived, and then refugees from the newly independent Haiti, influencing the French and Creole languages of Louisiana that had probably already started to influence each other. Throughout this period, some innovations spread from one 
Luc V. Baronian

area to another, irrespective of the different origins of the settlers and their descendants, thus giving Acadiana French the uniform look it has today.

Of course, more fieldwork, larger samples, more features, and more comparison with other North American and European dialects will be welcome to confirm the results obtained in this study. This brings me to conclude by highlighting the difficulties involved in Louisiana French and Creole fieldwork and research.

First and foremost, native speakers are aging and becoming harder to find and to approach. To find truly fluent speakers, my experience showed me that it is now absolutely necessary to avoid the urban areas and to focus on the rural communities. This in turn leads to the problem that it is even harder to approach speakers in the countryside than in a town. (How does one go about from farm to farm, asking if someone would drop whatever important task they are accomplishing on the field to answer some questions about French?) Ideally, I find it best to have a contact person in each area, someone who the other members of the community know and trust.

A second problem is that there is a large focus in the literature on lexical studies instead of grammatical ones, and measured phonetic data is virtually inexistent. While collection of individual words is to a large extent interesting, words, and especially lexical words (nouns, verbs, etc.) are easily borrowed from one dialect to another. The study of sound changes, which apply to vast classes of words, and grammatical words and constructions that are less easily borrowed, is by far more convincing to trace the historical relationships between dialects.

Finally, and this is what I hope this study will have helped rectify most, the literature is currently limited to descriptive - not comparative - studies. The few works that are devoted to the grammar of Louisiana French (e.g. Conwell and Juilland 1963 or Papen and Rottet 1997) make little or no effort to distinguish between the different parishes' speech; priority is typically given to one dialect or to the difference between French and Creole, or between Louisiana and Standard French. It is true that the several lexicons and dictionaries of Cajun French enjoy mentioning when a curious form of a word is attested in some region of France, but it would be much more interesting to be able to trace how this form made its way from France to Louisiana (perhaps via Quebec, Acadia, or Haiti), where in Louisiana it first entered, whether it spread to other regions of the state, and how many other features/words followed the same path.

Because we know the settlement pattern and history of the North American French colonies so well, they could provide an amazing testing ground for sociolinguistic theories and hypotheses, notably in the areas of language genesis and dialect contact. 
Pre-Acadian Cajun French

\section{References}

Brasseaux, Carl J. 1987. The Founding of New Acadia. Bâton Rouge: Louisiana State University Press.

Brown, Becky. 2003. Code-convergent borrowing in Louisiana French. Journal of Sociolinguistics 7(1):3-23.

Byers, B. 1988. Defining norms for a non-standardized language: A study of verb and pronoun variation in Cajun French. PhD diss., Indiana University, Bloomington.

Conwell, Marilyn J., and Alphonse Juilland. 1963. Louisiana French Grammar. La Haye: Mouton.

Cormier, Yves. 1999. Dictionnaire du français acadien. Saint-Laurent, QC: Fides.

Dulong, Gaston, and Gaston Bergeron. 1980. Le parler populaire du Québec et de ses régions voisines: atlas linguistique de l'Est du Canada. Québec: Ministère des communications, La Documentation québécoise.

Garrett, Andrew. 2003. The invention of Greek: Phonology, morphology, sociolinguistics. Presentation given to the Stanford Phonology Workshop.

Gilliéron, Jules, and Edmond Edmont. 1902-1910. Atlas linguistique de France. Paris: Campion.

Klingler, Thomas A. 2003a. Language labels and language use among Cajuns and Creoles in Louisiana. In T. Sanchez and U. Horesh, eds., Penn Working Papers in Linguistics 9(2):77-90.

--. 2003b. If I Could Turn my Tongue Like That: The Creole of Pointe Coupee Parish, Louisiana. Baton Rouge: Louisiana State University Press.

Klingler, Thomas A., Michael D. Picone, and Albert Valdman. 1997. The lexicon of Louisiana French. In A. Valdman, ed., French and Creole in Louisiana 145-181. New York: Plenum Press.

LaFleur, Amanda. Ms. A short essay on Cajun French, Louisiana State University. <http://www.artsci.lsu.edu/fai/Cajun/definition.html>.

Papen, Robert A., and Kevin J. Rottet. 1997. A structural sketch of the Cajun French spoken in Lafourche and Terrebonne Parishes. In A. Valdman, ed., French and Creole in Louisiana, 71-108. New York: Plenum Press.

Rottet, Kevin J. 2004. Inanimate interrogatives and settlement patterns in Francophone Louisiana. Journal of French Language Studies 14(2):169-188.

Valdman, Albert, and Thomas A. Klingler. 1997. The structure of Louisiana Creole. In A. Valdman, ed., French and Creole in Louisiana, 109-144. New York: Plenum Press.

Vaux, Bert. 1998. Sunshower summary. LINGUIST List 9.1795. 16 Dec. 1998. $<\mathrm{http}: / /$ www.linguistlist.org/issues/9/9-1795.html>.

von Wartburg, Walther. 1922-1972 (issued in parts). Französisches etymologisches Wörterbuch: eine Darstellung des galloromanischen Sprachschatzes. Bonn: F. Klopp. 
Luc V. Baronian

Luc V. Baronian

University of Ottawa

Pavillon Simard 202

60 University PVT

Ottawa ON K1N 6N5

Canada

baronian@uottawa.ca 